\title{
Analysis of Factors Influencing Market Participation of Smallholder Bean Farmers in Nyanza District of Southern Province, Rwanda
}

\author{
Jean Pierre Kamanzi Mbitsemunda ${ }^{1} \&$ Antoine Karangwa $^{1}$ \\ ${ }^{1}$ Rural Development and Agricultural Economics, University of Rwanda, Rwanda \\ Correspondence: Jean Pierre Kamanzi Mbitsemunda, Rural Development and Agricultural Economics, \\ University of Rwanda, Rwanda. E-mail: kampier02@gmail.com
}

\author{
Received: August 2, 2017 \\ Accepted: September 4, $2017 \quad$ Online Published: October 15, 2017 \\ doi:10.5539/jas.v9n11p99 \\ URL: https://doi.org/10.5539/jas.v9n11p99
}

\begin{abstract}
Rwanda remains trading very low volume of beans inside the country and across borders thereby becoming unable to meet national and international demands. This is exacerbated by low market participation of bean growers. This study assessed factors that influence market participation and extent of participation among bean growers in Nyanza district. Probit model was used to analyze the factors influencing market participation among bean growers while the extent of market participation was analyzed using Tobit model. The probit results indicated that factors that positively and significantly influenced the probability of farmers to participate in output market were bean quantity produced, market experience, and access to credit while factors that negatively and significantly influenced market participation decisions included distance to nearest market, age and access to off-farm activities. Tobit results revealed that factors that were found to have positive statistical significant impact on the extent of market participation were bean quantity produced, marketing experience and selling price. Contrary to earlier expectation, land size was found to have negative significant impact on the quantity of bean marketed. This is possibly an indication that the increased household's participation in output market is a function of farm productivity too.
\end{abstract}

Keywords: market participation, probit model, Rwanda, Tobit model

\section{Introduction}

There is strong empirical evidence that promoting market participation of smallholder farmers enhances their welfare as well as whole economic development (Wickramasinghe et al., 2014). Studies conducted in Africa and elsewhere find that commercialization increases household incomes because farmers realized their comparative advantages in agriculture farming activities and specialization (World Bank, 2015; Wickramasinghe et al., 2014). Additionally, it also provides chances for the off-farm employment (Braun, 1991). In considering that, Sub-Saharan African countries have recognized agriculture commercialization as one of the key components of their agenda for development (NEPAD, 2010; Brian \& Barret, 2014). In Rwanda, despite the government efforts to transform agriculture sector, many farmers remain largely in subsistence farming with little level of commercialization where nearly $21 \%$ of crop production is sold (NISR, 2012; MINAGRI, 2013; IPAR, 2015). While Common beans are the second most cultivated crop after bananas covering $20 \%$ of the total arable land in the country and grown by 90 of households, the commercialization of its overall production is reported to be at 19.8 percent (NISR, 2015). In 2013, the production quantity of beans topped to 438236 metric tons (FAOSTAT, 2013). Common bean is among the staple food crops that have received much attention from the government due to their importance for income generation, nutrition and food security (MINAGRI, 2007). That importance is expected to increase as Rwanda's population keeps rising, urbanization extends and income level increases.

Although Rwanda has these comparative advantages in bean farming, it remains trading very low volume of beans within Rwanda and across borders (NISR, 2015; USAID, 2013). According to USAID (2012), the traded volume of beans for Rwanda can be considerably increased if issues of bean marketing were effectively addressed. This makes it necessary to investigate the factors that influence the market participation of bean producers. The main objective of this study, therefore, is to provide the empirical information on the household's participation in the output market and to determine the factors that influence the market participation decision of smallholder bean farmers in Nyanza district of Rwanda using statistical and econometric models. The findings 
may be used in designing appropriate policies and strategies to ensure the market participation of bean farmers for them to gain the maximum market benefits.

\section{Literature Review}

The mainly acknowledged theory of agricultural commercialization is that the farm households are considered to be commercialized when aiming markets in their production decisions rather than being linked only to the amount of output they would possibly trade because of surplus production (Pingali \& Rosegrant, 1995). That is to say, production decisions of commercialized farmers are based on market information, while production decisions of subsistence farmers are based on production viability and subsistence requirements and trading only the remaining surplus production once household consumption requirements are satisfied (Pingali, 1995). Then, commercialization of agriculture may mean the production of agricultural goods to meet particular demands with the sale of unprocessed or processed produce to consumers or to manufactures when in the case of raw material for processors or industries. Agricultural marketing also incorporate the supply of inputs for production to farmers (Abbott, 1987).

Therefore, commercialization takes place both on the input and output aspects. The transformation of subsistence agriculture to more commercialized system based on well developed markets is a key in promoting economic growth and poverty reduction (Abbott, 1987). This can only occur when farmers participate in the output markets, by trading the largest component of their production to get income for buying inputs and other needs. Market participation is both a foundation and an outcome of economic development (Reardon et al., 2005). It promotes the linkage between the input and output aspects of agricultural markets (Gebremedhin et al., 2010). Smallholder farmers with low level of market participation often possess small agricultural harvests and they are as well the poorest (Mathenge et al., 2010). According to Brian and Barret (2014), higher market participation by smallholder farmers can promote yield by providing incentive, information and money for purchasing inputs. The major factors influencing household market participation are grouped in the conceptual framework as Household and household head characteristics (age, sex, education level and household size), livestock ownership (cattle, goats and poultry), household endowment of crop production factors (land, oxen, farm equipment and family labor), natural factors affecting crop production (rainfall, altitude and land fragmentation), market factors (distance to nearest market place and road, transport asset ownership, marketing experience, price information) and institutional services (access to extension and credit services, contract marketing) (Bellemare, \& Barret, 2006; Omiti, 2009; Goetz, 1992; Rios et al., 2008; Pngali, 1997).

While the benefits of market participation are commonly accepted, there is a small agreement on procedures for assisting integration of smallholder farmers into local and regional markets (Wickramasinghe et al., 2014). This is vital to identify possible approaches to stimulate their market access and participation for enhanced markets advantages. Better comprehension of such approaches will as well help governments and international agencies to eliminate constraints in market participation. Detection and removal of these constraints to integration of these households into local, regional and international markets are main priorities within Strategic plan for Agriculture transformation of Rwanda (MINAGRI, 2013). Yet, there are few empirical researches carried out to comprehend the drivers of commercialization for Rwandan farmers. This study, therefore, wants to identify the determinants of market participation of smallholder bean farmers in Nyanza district of southern province of Rwanda.

\subsection{Econometric Modeling for Market Participation}

The dependent variables analyzed in this study are market participation of bean farmers and degree of participation. Heckman two-stage approach, probit model, Tobit model and double hurdle model have been mostly used to determine market participation (Komarek, 2010). The econometric approach to be used depends on the nature of the response variable. This study attempts to model factors determining smallholder farmer's marketing decisions and sales volume decision in Nyanza district of Rwanda. Since market participation decision is a binary response variable, probit model is used to study factors influencing it (Gujarati, 2004; Egbetokun \& Omonona, 2012). Given that sales are only observed for a subset of the sample population because households who did not sell the output are reported as zero sales, the traded quantity function estimated on the selected sample, may not represent the population function due to self-selection problem (that is, individuals select themselves into group causing sample bias due to lack of probability sampling) (Heckman, 1979). For that reason, the parameters of the model can't be estimated by ordinary OLS because they would be biased and inconsistent (Wooldridge, 2003).

There are at least three alternatives to OLS method, which estimate unbiased, consistent and efficient parameters (Byron et al., 2012). The first alternative is to use the Heckman selection model (two-stage procedure) used by Boughton et al. (2007) and Goetz (1992). This alternative consists of two-stage estimating procedure. In step 1, 
one estimates the probability of market participation using the probit model. In step 2, one estimates the regression of the sales volume by ordinary OLS, which is conditional on the market participation (Wooldridge, 2003). That is, the model is estimated by adding to it a variable called the Inverse Mills Ration (IMR) as a regressor derived from the probit estimate during step 1. IMR is included in the second equation (step2) to control the selection bias and get consistent, unbiased and efficient parameters using OLS (Wooldridge, 2003). It seems rational that the Heckman selection model is suitable in this case since many smallholder farmers reported zero sales. Conversely, According to Ricker et al. (2011), the Heckman regression is made for incidental truncation, where zeros reflect missing values, that is, unobserved values or not selected (for example, the wage rate model where sample incorporates unemployed people). For that reason, a corner solution is more suitable in this case since, due to market and agronomic conditions, the zeros in the sample data revealed the household's rational choice rather than missing values (Byron et al., 2012) contrarily to what assumed by Heckman.

The other two alternatives to OLS method to estimate the farmer's marketing decision are both corner solution models. One is the Tobit model developed by James Tobin (1958) and the other one is the double-hurdle model developed by Cragg (1971). However, according to Gujarati (2004), the Heckman two-step approach may produce consistent estimates of the model but they are not as efficient as the estimates of the Maximum likelihood method (say, Tobit model). Tobit model has been used by many researchers to determine the degree of market participation like Martey (2012) when determining the extent of market participation among cassava growers in Ghana; other researchers include Adeoti (2014), Holloway et al. (2004), Bellemare and Barret (2006), and Komarek (2010). According to Komarek (2010), the double-hurdle model is not common in market participation literature. Therefore, this study used probit regression model and Tobit model to estimate the market participation and degree of participation respectively.

\section{The Methodology}

\subsection{The Study Area}

Nyanza district is one of the 30 districts in Rwanda and is located in southern province. The Nyanza town is also the capital of the southern province. The district is positioned between Huye and Ruhango, across the central road from Kigali to Bujumbura (Anonymous, 2013). According to NISR (2012), Nyanza district has 77,522 households with total area of $672 \mathrm{~km}^{2}$. About $88.1 \%$ of the district population is engaged in agricultural activities (Anonymous, 2013). Gender sensible, 53.3\% of the people in agricultural activities are women while men in agricultural activities are $34.8 \%$. The main crops grown are cassava and beans, but Coffee, maize and rice are also widely grown. Common bean is now the most grown crop since cassava was devastated by disease in the area. The district has some dynamic markets such as Nyanza, Ntyazo, Busoro and Rurangazi (Anonymous, 2013).

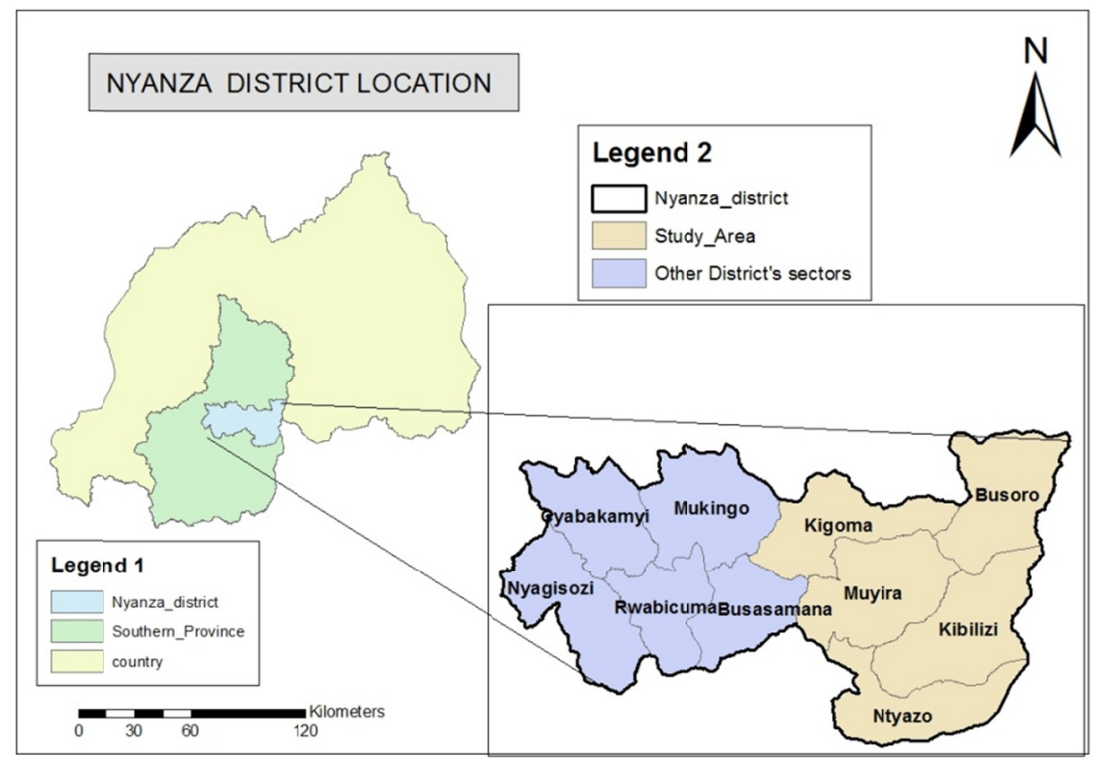

Figure 1. Study area of Nyanza district

Source: Adapted from Rwanda map. 


\subsection{Sampling Procedure}

The target population of the study was the smallholder growers of common bean in Nyanza district. Multi-stage sampling procedure was used in the selection of representative sample. A total of 100 farmers were selected from 5 sectors of Nyanza districts for the research using the formula proposed by Yamane (1967):

$$
\mathrm{n}=\mathrm{N} / 1+\mathrm{N}(\mathrm{e})^{2}
$$

Where,

$\mathrm{n}=$ is the sample size, $\mathrm{N}=$ is the Population size and $\mathrm{e}=$ is the level of precision (for confidence interval of $90 \%$, equal to $10 \%$ ). The data collected included, among them, some household characteristics, socioeconomic aspects, institutional characteristics and market aspects.

\subsection{Data Collection and Analysis}

Semi-structured questionnaires were used to collect data through face-to-face interviews with representative sample of common bean growers in Nyanza district. Since farmers do not keep farm records, this study relied on farmers' recall for some basic information. Raw Data collected from the field was coded, and cleaned to ensure consistency, uniformity and accuracy. Data entry was done using Excel and then STATA was used to process the data. Both descriptive and econometric analyses were performed for analyzing the collected data. Probit regression model was used to analyze the determinants influencing market participation decisions and Tobit model was then used to analyze the extent of market participation. The decision to either participate in the market or not and the extent of participation were treated as dependent variables and estimated independently.

\subsection{Farmers Choice to Participate in the Market}

Before using the probit regression model, descriptive statistics (means, percentages, t-test, probabilities and chi-square test) was used to describe the socioeconomic features of bean market participants and non-market participants.

Probit model was used to estimate the factors influencing market participation decision of bean growers in the study area. According Egbetokun and Omonona (2012), the probit model to analyze the farmers' decision to participate in the output market can be computed from the standard normal cumulative distribution function as follows:

$$
P(0,1)=P(y=1 \mid x)=P\left(Z_{i}^{*} \leq Z\right)=P\left(Z_{i}^{*} \leq \beta_{1}+\beta_{2} x i\right)=F\left(\beta_{1}+\beta_{2} x i\right)
$$

Where,

$P(0,1)$ or $P(y=1 \mid x)$ is the probability that an individual household participate in the market given the explanatory variables $\mathrm{X}_{i}$ hypothesized to affect farmers 'decision to participate in bean market and $\mathrm{Y}$ is a dependent variable which takes on the value of 1 if the farmers participate in the bean market and 0 otherwise. Thus, the model specification on the decision of whether to participate in the market or not can be estimated as follows:

$$
\begin{aligned}
\mathrm{P}(0,1)=\mathrm{MPD}= & \beta_{0}+\beta_{1} \text { age }+\beta_{2} \text { sex }+\beta_{3} \text { educ }+\beta_{4} \text { familylabor }+\beta_{5} \text { landsize }+\beta_{6} \text { offfarm } \\
& +\beta_{7} \text { accesscred }+\beta_{8} \text { distmark }+\beta_{9} \text { membership }+\beta_{10} \text { extension } \\
& +\beta_{11} \text { markexp }+\beta_{12} \text { beanquantity }+\beta_{13} \text { familysize }+\varepsilon i
\end{aligned}
$$

Where,

MPD $=$ is the market participation decision which can take the value of 1 if the household participated in the market or 0 if it does not.

\subsection{The Volume of Beans Traded}

To analyze the factors affecting the level of market participation, Tobit regression model was chosen. Tobit model was developed by James Tobin (1958) and is used to address the problem with data not capturing all the information about the regressand or dependent variable. This dependent variable is called the "censored dependent variable" or "dependent variable with ceiling effect" as the information on the dependent variable is available only for some observations (individuals). According to Gujarati (2004), the Heckman two stage models is the alternative to Tobit model but the estimates from Heckman model are consistent but not efficient as the estimates from the maximum likelihood of Tobit model. Tobit model has been applied in many studies including (Martey, 2012) when determining the extent of market participation among cassava growers in Ghana. The model specification on the degree of participation can thus be estimated as follows: 


$$
\begin{aligned}
\mathrm{TRV} & =\beta_{0}+\beta_{1} \text { age }+\beta_{2} \text { sex }+\beta_{3} \text { educ }+\beta_{4} \text { familylabor }+\beta_{5} \text { landsize }+\beta_{6} \text { offfarm } \\
& +\beta_{7} \text { accesscred }+\beta_{8} \text { distmark }+\beta_{9} \text { membership }+\beta_{10} \text { extension }+\beta_{11} \text { markexp } \\
& +\beta_{12} \text { beanquantity }+\beta_{13} \text { familysize }+\beta_{14} \text { sellprice }+\mu i
\end{aligned}
$$

Where,

TRV is the traded volume of beans.

\subsection{Description of Variables Used in the Empirical Models}

\begin{tabular}{|c|c|c|c|c|}
\hline Variable & Variable Name & Variable type & Variable measurement & Expected sign \\
\hline \multicolumn{5}{|c|}{ Dependent Variables } \\
\hline MPD & Bean market participation decision & Qualitative/Dummy & 1 if participated, 0 otherwise & N.A \\
\hline TRV & Extent of participation & Continuous & $\begin{array}{l}\text { Quantity of bean supplied to the market } \\
\text { in kilogram }\end{array}$ & N.A \\
\hline \multicolumn{5}{|c|}{ Explanatory Variables } \\
\hline Age & age of household head & Continuous & Age of household head in Years & $+/-$ \\
\hline Sex & sex of household head & Dummy & 1 if household head is male, 0 otherwise & + \\
\hline Years of school & Years of schooling & Continuous & Number of years in school & + \\
\hline Family labor & Family labor & Continuous & Number of people engaged in the family farm & + \\
\hline Land size & Farm size & Continuous & $\begin{array}{l}\text { Size of land under cultivation of farm } \\
\text { household in Hectares }(\mathrm{Ha})\end{array}$ & + \\
\hline Off-farm & Off farm activities & Dummy & 1 if participated, 0 otherwise & - \\
\hline Beanquantity & Quantity of bean produced & Continuous & The production of bean in kilogram & + \\
\hline Accesscred & Access to credit & Dummy & 1 if used credit, 0 otherwise & + \\
\hline Distmark & Distance to market & Continuous & The distance to nearest market in kilometers & - \\
\hline Membership & Group membership & Dummy & 1 if a member of cooperative, 0 otherwise & + \\
\hline Selling Price & Selling price & Continuous & Price per kilogram of bean & + \\
\hline Extension & Number of extension visit/year & Continuous & Number of visits in the year & + \\
\hline Markexp & Marketing experience & continuous & Number of years engaged in crop production & + \\
\hline Familysize & Number of members of household & continuous & Number of members & - \\
\hline
\end{tabular}

Specific variables to include in the model are described in the following table:

Table 1. Description of the variables in the empirical models

Source: Author's definitions.

\section{Results and Discussion}

This section is divided in three subsections. The first subsection describes the sample and provides the socioeconomic characteristics of farming households focusing on the variables of interest for the probit and Tobit model analysis, and then the results were disaggregated by market participation. The second and third subsections detail the results from probit regression and Tobit model respectively by providing the in-depth explanation of significant variables.

\subsection{Descriptive Results}

The collected data from the 100 subsistence bean farmers are analyzed to depict the demographic, economic and land specific characteristics of bean growers in Nyanza district. Among the sampled farmers, 69 percent were bean market participants while 31 percent were non-market participants. Descriptive statistics (percentages, mean, t-test and chi-square test) indicated that Market participants and non-market participants had statistical significant differences with regards to land size, bean quantity produced, cooperative membership, credit accessibility, frequency of visits by extension agents, market experience and distance to nearest market. The key features of the variables used in the current research are shown in the Table 2. 
Table 2. Brief description of collected data

\begin{tabular}{|c|c|c|c|c|}
\hline Characteristics & & $\begin{array}{l}\text { Market-participants } \\
(n=69)\end{array}$ & $\begin{array}{l}\text { Non-market-participants } \\
(\mathrm{n}=\mathbf{3 1})\end{array}$ & \\
\hline & & Mean & Mean & t test \\
\hline Age & & 47.68 & 49.10 & \\
\hline Education(years of schooling) & & 4.78 & 4.48 & \\
\hline Family size & & 5.13 & 4.97 & \\
\hline Land size & & 0.72 & 0.55 & $-1.4467 *$ \\
\hline Quantity harvested & & 256.84 & 85.00 & $-3.7253 *$ \\
\hline Market experience & & 10.96 & 3.32 & $5.5418^{*}$ \\
\hline Distance to market & & 2.57 & 5.00 & $4.1314^{*}$ \\
\hline \multirow[t]{2}{*}{ Extension frequency } & & 1.93 & 1.13 & $2.6^{*}$ \\
\hline & & Percentage & Percentage & Chi2 \\
\hline \multirow[t]{2}{*}{ Access to credit } & Yes & 21.74 & 6.45 & $3.54 *$ \\
\hline & No & 78.26 & 93.55 & \\
\hline \multirow[t]{2}{*}{ Group membership } & Yes & 52.2 & 22.6 & $7.6428 *$ \\
\hline & No & 47.8 & 77.4 & \\
\hline \multirow[t]{2}{*}{ Access to off activities } & Yes & 17.4 & 16.1 & \\
\hline & No & 82.6 & 83.9 & \\
\hline
\end{tabular}

Note. $n=100, *$ denotes significance at $\alpha=5 \%$.

Source: Survey data (2017).

\subsection{Factors Affecting Market Participation Decision in Nyanza District}

In order to achieve the objectives of the study, some socioeconomic factors that were hypothesized to affect the decision to participate in the output market were included in the probit regression model and the results are represented in the Table 3.

From the Table 3, it can be noticed that the likelihood ratio statistics as indicated by chi-square are highly significant $(\mathrm{P}<0.0000)$, suggesting that all the model parameters were jointly significant in explaining the dependent variable. The pseudo R2 were 0.55 suggesting that the specification fits the model well and the variables included in the model explain $55 \%$ of variation in the decision of market participation, indicating the goodness of fit of the model. The results indicated that explanatory variables-bean quantity produced, market experience and access to credit-have positively and significantly influenced the probability of being commercial farmer. However, distance to nearest market, age and access to off-farm activities had negative significant effect on the decisions of farmers to participate in the market. The marginal effects were used to interpret the change in probability of market participation among smallholder farmers. 
Table 3. Probit model results for factors influencing market participation

\begin{tabular}{llllll}
\hline Variables & Coefficient & Std. Err. & Marginal effect (dy/dx) & $\mathbf{Z}$ & $\mathbf{P}>|\mathbf{z}|$ \\
\hline Age & $-0.048^{* *}$ & 0.025 & -0.0075 & -1.91 & 0.056 \\
Sex & 0.587 & 0.574 & 0.091 & 1.02 & 0.307 \\
Years of education & -0.142 & 0.0954 & -0.022 & -1.50 & 0.134 \\
Family size & 0.066 & 0.117 & 0.0104 & 0.57 & 0.568 \\
Family labor & -0.0860 & 0.260 & -0.013 & -0.33 & 0.741 \\
Group membership & 0.470 & 0.460 & 0.073 & 1.02 & 0.307 \\
Land size & -0.372 & 0.517 & -0.058 & -0.72 & 0.471 \\
Bean quantity produced & $0.00870^{* * *}$ & 0.003 & 0.0013 & 2.73 & 0.006 \\
Market experience & $0.103062^{* * *}$ & 0.0349 & 0.016 & 2.95 & 0.003 \\
Distance to market & $-0.245^{* * *}$ & 0.0919 & -0.038 & -2.67 & 0.008 \\
Extension frequency & 0.153 & 0.167 & 0.023 & 0.92 & 0.359 \\
Access to credit & $2.129^{* *}$ & 0.8935 & 0.33 & 2.38 & 0.017 \\
Off-farm activities & $-1.845^{* * *}$ & 0.656 & -0.288 & -2.81 & 0.005 \\
Constant & 1.7852 & 1.659 & & 1.08 & 0.282 \\
LR chi2(13)=68.29 & & & & \\
Prob $>$ chi2 $=0.0000$ & & & &
\end{tabular}

Note. $* * *=1 \%$ significance level, $* *=5 \%$, and $*=10 \%$ significance level.

Source: Survey data (2017).

The probit results showed that 'bean quantity produced' had positive and significant effect on the household decision to participate in the bean market $(\mathrm{p}=0.006)$. The sign of the coefficient is positive and it means that if a farmer get much more production, the probability of taking a decision to participate in the output market increases. The marginal effect revealed that a unit increase in the bean quantity produced increased the probability of market participation by $0.13 \%$. This is in line with the findings of Pender (2007) who observed that increasing the production of food crops is the most significant factor that increase the crop sales in Ethiopia. Mussema (2012) also found that when farmers produce more pepper, they are more likely to participate in the output market.

The results also revealed that 'market experience' had positive significant effect on the decision of farm family to participate in the output market $(\mathrm{p}=0.003)$. The marginal effects showed that the increase by one year in market experience increases the probability of a household to participate in the output market by 1.6 percent. This means that the long trading experience decreases the probability of being a subsistence farmer because being experienced insinuates the fact of having easy access to market information and having social networks with marketing players which reduces marketing cost. This is in line with the findings of World Bank (2007) that reported that experience and skills are the fundamental factors in commercializing the smallholder agriculture.

In terms of access to credit, the probit results in Table 3 indicated that the access to credit is found to have positive significant impact on the household's decision to participate in the bean market $(p=0.017)$. This means that when farmers have access to credit, the probability of farmers' orientation towards commercialization increases in the study area. The shift from lack of credit accessibility to credit access would increase the probability of market participation by 33.2 percent. This is because the credit accessibility allows farmers to purchase the improved agricultural inputs such as fertilizers, seeds and other production technologies which in turn increase the production and thus the marketable surplus. This finding is consistent with that of Randela (2008) who also found that the access to credit had positive impact on the probability of household's decisions to participate in the market of cotton in South Africa.

However, the probit results in Table 3 revealed that distance to nearest market was found to have negative significant influence on the probability of smallholder farmers to participate in the output market $(p=0.008)$. The sign negative means that as distance to nearest market increases, the probability of farm household's orientation towards commercialization of their farming system reduces in the study area. This is because as the distance to market increases, the transportation cost increases as well, this is a disincentive to market 
participation. The marginal effect revealed that as the distance to nearest market increase by one kilometer, the probability of household to participate in the output market decreases by 3.8 percent. This is in line with the findings of Eskola (2005) who reported that the distance to nearest market was the significant factor that affected the farmers' degree of commercialization in Tanzania.

In terms of age of household, the probit results showed that age had negative impact on the farmers' decision to participate in the output market $(\mathrm{p}=0.056)$. The marginal effect of probit results indicated that the increase in one year would reduce the probability of farmers' orientation towards commercialization by 0.8 percent. This may be due to the fact that older people are more risk averse, slow to adopt technology and less physically fit to transport the production to the market. This finding is consistent with the findings of Alene et al. (2008) and Heltberg (2002) who found that besides being risk averse, older farmers are slow in adopting technology which may reduce their production in Kenya and Mozambique respectively. Muhongayire and Hitayezu (2013) found that older farmers were found to participate less in the credit use in eastern part of Rwanda because of being risk averse.

It was expected that income from off-farm activities may have positive or negative impact on market participation because this income may strengthen the farming practice or may make the household reluctant to depend on bean production to get money. Therefore, as shown in Table 3, the probit results revealed that the access to off-farm activities had a negative significant impact on the farmers' decisions to participate in the output market $(\mathrm{p}=0.005)$ in the study area. This means that if farmers participate in alternative activities to farm-income source, they are less likely to involve in food production thereby reducing the household's position in crop market. The marginal effects suggest that if a household involves in one alternative work to on-farm income source, the probability of market participation decreases by 28.8 percent. This finding indicates that households with high off-farm income are inclined to be non-participants in crop market because they tend to generate cash from off-farm activities rather than agricultural commodities like common bean in the study area. This is consistent with the findings of Gebremedhin and Jaleta (2012) in Ethiopia. This was also supported by the findings of Martey (2012) who found that the increase in off-farm income reduced the market participation of maize growers and level of participation among the cassava growers in Ghana.

Contrarily to earlier expectations, variables-years of education, land size, family size, family labor, and sex and extension service frequency-were found to have no significant influence on the household's decision towards marketing their bean production. In addition, the directions of the effects of some variables were found to be opposed to earlier expectations. For instance, years of schooling indicated the unpredicted negative sign. The possible justification may be that a number of young families are interested by other occupation rather than agriculture.

\subsection{Factors Affecting the Level of Market Participation in Nyanza District}

The Tobit model was used to analyze factors affecting the degree of market participation. From the Table 4, it can be observed that the likelihood ratio statistics as shown by chi-square are highly significant $(\mathrm{P}<0.0000)$ suggesting that the model has strong explanatory power. The results of Tobit model showed that most of the variables tested for influencing the degree of market participation had the expected signs. However, only bean quantity produced, market experience and selling price have positively and significantly affected the extent of market participation. Land size is fundamental because transaction costs are mainly fixed costs that can be spread across more outputs on big farms. Contrarily to earlier expectation, land size is found to have unexpected negative impact on the level of market participation in the study area. Nevertheless, sex, years of education and credit accessibility have expected positive sign but they were statistically insignificant. On the other hand, age, family size and access to off-farm activities had expected negative sign but they were statistically insignificant. 
Table 4. Tobit model results for factors influencing the level of market participation

\begin{tabular}{|c|c|c|c|c|}
\hline Variables & Coefficients & Std. Err. & $\mathbf{t}$ & $\mathbf{P}>|\mathbf{t}|$ \\
\hline Age & -0.648 & 0.5898 & -1.100 & 0.2750 \\
\hline Sex & 8.648 & 16.5478 & 0.52 & 0.603 \\
\hline Education & 0.765 & 1.9452 & 0.39 & 0.7240 \\
\hline family size & -3.065 & 3.01637 & -1.02 & 0.312 \\
\hline Family labor & -8.852 & 8.453 & -1.05 & 0.298 \\
\hline Group membership & -18.778 & 12.1465 & -1.55 & 0.126 \\
\hline Land size & $-28.132 * *$ & 13.770 & -2.04 & 0.044 \\
\hline Bean quantity produced & $0.764 * * *$ & 0.033 & 22.83 & 0.000 \\
\hline Selling price & $0.208 * * *$ & 0.039 & 5.32 & 0.0000 \\
\hline Experience & $1.838^{*}$ & 1.071 & 1.71 & 0.090 \\
\hline Distance to market & 0.747 & 2.476 & 0.30 & 0.764 \\
\hline Extension frequency & 2.125 & 4.535 & 0.47 & 0.641 \\
\hline Access to credit & -1.785 & 14.732 & 0.12 & 0.904 \\
\hline Off-farm activities & -1.9005 & 15.0588 & -0.13 & 0.900 \\
\hline Constant & -67.6741 & 38.215 & -1.77 & 0.080 \\
\hline Sigma & 46.338 & 4.0149 & & \\
\hline \multicolumn{5}{|l|}{ Number of obs $=100$} \\
\hline \multicolumn{5}{|l|}{$L R \operatorname{chi} 2(14)=253.34$} \\
\hline Prob $>$ chi $2=0.0000$ & & & & \\
\hline
\end{tabular}

Source: Survey data (2017).

Tobit estimation results in Table 4 indicated that farm size was statistically significant at $5 \%$ but has unexpected negative influence on level of market participation of households. This inverse relationship between farm size and levels of market participation suggests that households with relatively large farm size are likely to have low levels of market participation. This is possibly a signal that improved bean market participation is as well a function of land production efficiency (Randela \& Groenewald, 2008). If this is true, it insinuates that any initiative in the bean sector must be anteceded by the efforts to improve the productivity of the existing land under farming. The similar findings were observed by Randela and Groenewald (2008) who found the negative relationship between the farm size and level of market participation of cotton farmers in South Africa. Govereh and Jayne also found (1999) that the farm size has significant negative impact on food crop productivity since the increase in land size pulled farmer's orientation towards diversification into cash cropping in Zimbabwe.

However, the results in Table 4 indicated that 'bean quantity produced' had high positive significant influence on the level of commercialization in the study area $(p=0.0000)$. The Tobit results showed that the increase in bean output by one kilogram increases the quantity of bean supplied to market by $0.76 \mathrm{~kg}$. This was eventually expected since households who have greater production have more surpluses they can sell. This is in line with the findings of Reyes et al. (2009) who found that quantity of potato produced influenced positively and significantly the market participation and level of participation in Angola. Rios and Gerald (2008) also reported that farmers with more production have surplus to participate in the output market, ceteris paribus.

Selling price significantly and positively influenced the extent of market participation $(p=0.0000)$. The results showed that the increase in price by one unit increases the quantity of bean supplied to market by $0.2 \mathrm{~kg}$ in the study area. Price is the crucial instrument in marketing because lower price is a disincentive to market participation. These study findings are consistent with the economic theory, law of supply, which stipulates that the increase in price of good leads to the increase in quantity supplied (Mas-Colell \& Green, 1995). Goetz (1992) found a positive significant relationship between price and quantity of food grain supplied to market in Sub-Sahara Africa.

Finally from the Table 4, it can be observed that market experience was another factor found to have positive significant effect on the level of household commercialization $(p=0.09)$. The Tobit results revealed that the increase in one year of market experience, the quantity of bean supplied to market increases by $1.8 \mathrm{~kg}$. A possible explanation is that more experienced farm households tend to have more personal contacts and social 
networking, permitting further discovery of trading opportunities at lower costs. Similar findings were found by Matungul (2001) and Makhura (2001) who discovered that some experience about the market helped farmers to overcome some fixed transaction costs in South Africa.

\section{Conclusion and Recommendations}

\subsection{Conclusion}

Policy creators in developing country like Rwanda are challenged with increasing income to smallholder farmers who mainly depend on subsistence agriculture on one hand and provide more affordable food commodities to non-producers on the other hand. A common approach adopted was the transformation of subsistence agriculture to market-oriented agriculture which implies production decisions based on market signals and substantial participation in input and output markets. This is believed to be an approach that can achieve the welfare improvements of these groups of people. However, the lack of full participation in markets prevents them from transiting into commercialized farming and thus causing their low contribution to economic growth and their welfare boosts. In Rwanda, the drivers of subsistence agriculture commercialization are not fully analyzed. This study was an attempt to fill this gap of knowledge in drivers of market participation decisions.

The results presented in this study revealed some differences between market participants and non-market participants. The non-n market participants were constrained by various factors in marketing, making it inflexible for them to commercialize. Such factors include low access to credit which limits their ability to afford inputs, low production, high distance to nearest market which is a disincentive to market participation, low access to extension agents, low use of improved seeds and fertilizers which limit their potential to produce surplus for market as noticed in their low volume they produced.

The econometric results indicated the factors that can promote the market participation among smallholder farmers such as the quantity of bean produced, the selling price, the access to credit, rural infrastructure development in order to reduce transaction cost (road), access to improve seeds and fertilizers to improve productivity. In terms of land size, the study showed that the negative relationship between farm size and market participation is a possible indication that the level of farm commercialization is a function of land productivity (Randela, 2008).

\subsection{Recommendation}

The study recommends that more efforts should be done to establish more sales points in rural agricultural areas in order to reduce the transaction costs to promote market participation.

The study findings appeared to indicate that bean quantity produced is among the leading significant drivers; hence efforts to increase production abilities are very imperative to promote commercialization of subsistence agriculture. Precisely, the promotion of input stock market is recommended to facilitate more access to improved seeds (high yielding varieties) which is currently limiting factor in the study area and use of fertilizers in order to boost productivity.

The study found the negative relationship between level of market participation and land size which may have probably resulted from very low land productivity, therefore the study recommends that any initiative in the bean sector must be anteceded by the efforts to improve the productivity of the existing land under cultivation.

The output selling price is an incentive for farm families to supply more output to market as revealed by this study. Therefore, in order to promote the marketed surplus, more efforts from the government and non-government institutions should concentrate on lowering the transaction costs and supporting the marketing extension services and market linkages among diverse market players. This will help households to farm in accordance to market requirements and standards, having information on price trends, future demands and dynamics in consumption preferences.

The study recommends that the government should identify a pathway to create better credit services to households with minimal farm size in order to create viable conditions to shift from subsistence farming to market-oriented farming, allowing at the same time others to afford the production inputs that boost farm production. The empirical results showed that credit accessibility boosted crop production which is a vital driver for commercializing smallholder agriculture.

\section{References}

Abbott, C. (1987). Agricultural marketing for the developing world. Cambridge University Press, UK.

Adeoti, A., Oluwatayo, B. I., \& Soliu, O. R. (2014). Determinants of Market Participation among Maize Producers in Oyo State, Nigeria. Nigerian Journal of Economics, 4(7), 1115-112. https://doi.org/10.9734/ BJEMT/2014/7826 
Alene, A. D., Manyong, V. M., Omanya, G., Mignouna, H. D., Bokanga, M., \& Odhiambo, G. (2008). Smallholder Market Participation under Transactions Costs: Maize Supply and Fertilizer Demand in Kenya. Food Policy, 33(4), 318-328. https://doi.org/10.1016/j.foodpol.2007.12.001

Anonymous. (2013). Nyanza Development District Plan. Nyanza, Rwanda.

Bellemare, M. F., \& Barret, C. B. (2006). An ordered Tobit Model of market participation: Evidence from Kenya and Ethiopia. American Journal of Agricultural Economics, 88(2), 324-337. https://doi.org/10.1111/ j.1467-8276.2006.00861.x

Braun, Von J., Bouis, H., \& Kennedy, E. (1991). Conceptual framework. In J. von Braun \& E. Kennedy (Eds.), Agricultural commercialization, economic development, and nutrition in Rwanda (Research Report 85). Johns Hopkins University Press, Baltimore, Maryland, USA.

Brian, D., \& Barrett, C. B. (2014). Agricultural Factor Markets in Sub-Saharan Africa: An Updated View with Formal Tests for Market Failure. Policy Research Working Paper (No. 7117). World Bank Group, Washington, DC, World Bank.

Byron, R., Donovan, C., Bernsten, R., \& Maredia, M. (2012). Market participation and sale of potatoes by smallholder farmers in the central hihghlands of Angola: A double hurdle model (No. 126655). Triennial Conference, Foz do Iguaçu, Brazil, August 18-24, 2012, International Association of Agricultural Economists.

Cragg, J. G. (1971). Some statistical models for limited dependent variables with application to the demand for durable goods. Econometrica, 39(5), 829-844. https://doi.org/10.2307/1909582

Egbetokun, A., \& Omonona, B. T. (2012). Determinants of Farmers' Participation in Food Market in Ogun State. Global Journal of Science Frontier Research Agriculture and Veterinary Sciences, 12(9), Version 1.

Eskola, E. (2005). Commercialization and Poverty in Tanzania: Household-Level Analysis (Discussion Paper, Department of Economics, University of Copenhagen, Copenhagen). Retrieved from http://www.econ. ku.dk/wpa/pink/2005/0527.pdf

FAOSTAT (Food and Agricultural Organization Statistical Division). (2013). Statistical Year book. Retrieved from http://faostat3.fao.org/browse/Q/QC/E

Gebremedhin, B., \& Jeleta, M. (2010). Commercialization of Smallholders: Is Market Participation Enough? 2010 Conference, Cape Town, South Africa, September 19-23, African Association of Agricultural Economists (AAAE), Agricultural Economists Association of South Africa (AEASA).

Gebremedhin, B., \& Moti, J. (2012). Interdependence of smallholders' net market positions in Mixed-crop livestock systems of Ethiopian highlands. Journal of Development and Agricultural Economic, 4(7), 199-209.

Goetz, S. J. (1992). A Selectivity model of household food marketing behavior in Sub-Saharan Africa. American Journal of Agricultural Economics, 74(2), 444-452. https://doi.org/10.2307/1242498

Govereh, J., \& Yayne, T. S. (1999). Effect of cash crop on food crop productivity in Zimbabwe. Synergies or Trade-off. Policy synthesis for USAID-Africs bureau office of sustainable development. Agricultural Economics, 28(2003), 39-50.

Gujarati, D. N. (2004). Basics Econometrics (4th ed.). McGraw-Hill, New York, USA.

Heckman, J. (1979). Sample Selection Bias as a Specification Error. Econometrica, 47(1), $153-161$. https://doi.org/10.2307/1912352

Heltberg, R., \& Tarp, F. (2002). Agricultural Supply Response and Poverty in Mozambique. Food Policy, 27(2), 103-12. https://doi.org/10.1016/S0306-9192(02)00006-4

Holloway, G., Nicholson, C., Delgado, C., Staal, S., \& Ehui, S. (2004). A Revised Tobit Procedure for Mitigating bias in the Presence of Non-zero Censoring with an Application to Milk Market Participation in the Ethiopian Highlands. Journal of Agricultural Economics, 31, 97-106. https://doi.org/10.1111/j.1574-0862. 2004.tb00224.x

IPAR (Institute of Policy Analysis and Research). (2015). Annual analysis of Rwanda's agriculture budget expenditure, 2015-2016. Action aid International Rwanda. 
Komarek, A. (2010). The Determinants of Banana Market Commercialization in Western Uganda. African Journal of Agricultural Research, 5(9), 775-784. Retrieved from http://www.academicjournals.org/journal/ AJAR/article-abstract/5CD7A7427387

Makhura, M. T. (2001). Overcoming transaction costs barriers to market participation of Smallholder farmers in the Northern Province of South Africa (PhD dissertation, University of Pretoria, Pretoria, South Africa). Retreived from http://hdl.handle.net/2263/27659

Martey, E., Al-Hassan, R. M., \& Kuwornu, J. K. M. (2012). Commercialization of Smallholder agriculture in Ghana: A Tobit regression analysis. African Journal ofAgricultural Research, 7(14), 2131-2141. Retrieved from http://www.academicjournals.org/article/article1380982407_Martey\%20et\%20al.pdf

Mas-Colell, A., Whinston, D. M., \& Green, R. J. (1995). Microeconomic Theory. Oxford, University Press.

Mathenge, M., Place, F., Olwande, J., \& Mitheofer, D. (2010). Market Participation among poor rural Households in Kenya. Study report. World Agroforestry Center, Tegemeo Institute of agricultural Policy and Development, Egerton University and World Agroforestry Center.

Matungul, P. M., Lyne, M. C., \& Ortmann, G. F. (2001). Transaction costs and crop marketing in the communal areas of Impendle and Swayimana, KwaZuluNatal, South Africa. Development Southern Africa, 18(3), 347-363. https://doi.org/10.1080/03768350120070017

MINAGRI (Ministry of Agriculture and Animal Resources). (2007). Annual report. Kigali, Rwanda.

MINAGRI (Ministry of Agriculture and Animal Resources). (2010). Strategies for Sustainable Crop Intensification in Rwanda. Kigali, Rwanda.

MINAGRI (Ministry of Agriculture and Animal Resources). (2013). Annual report. Kigali, Rwanda.

MINAGRI (Ministry of Agriculture and Animal Resources). (2013). Strategic plan for agriculture transformation in Rwanda. Kigali, Rwanda.

Muhongayire, V., Hitayezu, P., Mbatia, O., \& Mukoya, S. (2013). Determinants of farmers'participation in formal credit markets in rural Rwanda. Journal of Agricultural Science, 4(2), 87-94.

Mussema, M., \& Dawit, A. (2012). Red pepper marketing in Siltie and Alaba in SNNPRS of Ethiopia: Factors affecting households' marketed pepper. International Research Journalof Agricultural Science and Soil Science, 2(6), 261-266.

NEPAD (New Partnership for Africa's Development). (2010). Abuja Declaration on Fertilizer for an African Green Revolution. Abuja, Nigeria.

NISR (National Institute of Statistics of Rwanda). (2012). The third integrated Household living conditions Survey (EICV3). Kigali, Rwanda.

NISR (National Institute of Statistics of Rwanda). (2015). The Fourth integrated Household living conditions Survey (EICV4). Kigali, Rwanda.

NISR (National Institute of Statistics of Rwanda). (2015). The seasonal agriculture survey. Kigali, Rwanda.

Omiti, J., \& McCullough, E. (2009). Factors Influencing the Intensity of Market Participation by Smallholder Farmers; A Case Study of Rural and Peri-Urban Areas of Kenya, African Journal of Agricultural and Resource Economics, 3(1), 52-82.

Pender, J., \& Alemu, D. (2007). Determinants of smallholder commercialization of food crops: Theory and evidence from Ethiopia. IFPRI (International Food Policy Research Institute), Discussion Paper No. 75, Washington DC, USA.

Pingali, P. L., \& Rosegrant, M. W. (1995). Agricultural commercialization and diversification Process and polices. Food Policy, 20(3), 171-185. https://doi.org/10.1016/0306-9192(95)00012-4

Randela, R., Alemu, G. Z., \& Groenewald, A. J. (2008). Factors enhancing market participation by small-scale cotton farmers. Agrekon, 47(4), 451-469. https://doi.org/10.1080/03031853.2008.9523810

Reardon, T., \& Timmer, C. P. (2005). Transformation of Markets for Agricultural Output in Developing Countries Since 1950: How Has Thinking Changed? Handbook of Agricultural Economics.Amsterdam, the Netherlands. 
Ricker-Gilbert, J., Jayne, T., \& Chirwa, E. (2011). Subsidies and Crowding Out: A Double-Hurdle Model of Fertilizer Demand in Malawi. American Journal of Agricultural Economics, 93(1), 26-42. https://doi.org/ 10.1093/ajae/aaq122

Rios, A. R., William, A. M., \& Gerald, E. (2008). Linkages between Market Participation and Productivity: Results from a Multi-Country Farm Household Sample. Prepared for Presentation at the American Agricultural Economics Association, Annual Meeting, Orlando, Florida.

Tobin, J. (1958). Estimation of Relationships for Limited Dependent Variables. Econometrica, 26, 24-36. https://doi.org/10.2307/1907382

USAID (United States Agency for International Development). (2012). The business case for investing in the processing and Canning of Common Beans in Rwanda. Feed the Future (FtF) Program. Monitor group, USAID, Rwanda.

USAID (United States Agency for International Development). (2013). Rwanda cross-border agricultural trade analysis. Enabling Agricultural Trade (EAT) Project. Fintrac Inc, USAID, Rwanda.

Wickramansinghe, U., Norah, O., Arnold, D., \& Patiken, J. R. (2014). Market participation of smallholder agricultural household in Papua New Guinea. Indonesia.

Wooldridge, J. M. (2003). Econometric Analysis of Cross Section and Panel Data. Cambridge: MIT Press.

World Bank. (2007). World Development Report 2008: Agriculture for development: Overview. Washington, DC, USA.

World Bank. (2015). Transformation In African Agriculture: Why Do We Need It and What Will It Take? Rwanda Agriculture Knowledge Day. March 19, 2015, Kigali, Rwanda.

Yamane, T. (1967). Statistics: An Introductory Analysis (2nd ed.). New York: Harper and Row.

\section{Copyrights}

Copyright for this article is retained by the author(s), with first publication rights granted to the journal.

This is an open-access article distributed under the terms and conditions of the Creative Commons Attribution license (http://creativecommons.org/licenses/by/4.0/). 